Authors' version. Please see the version of record published in Örtenblad, A. (2021). Debating Equal Pay for All: Economy, Practicability and Ethics (pp.255-266). Palgrave Macmillan. Available at: https://doi.org/10.1007/978-3-030-53575-9_16

\title{
Equal pay as a precondition of justice?
}

Daniel Pointon and Matthew Sinnicks

\section{INTRODUCTION}

Equality is typically presumed to be an end of justice, however, in this chapter, we argue that equality may be better understood as a condition of justice. This is because inequality is deleterious to the kinds of relationships required to foster communities which sustain justice, both within individual workplaces and within the polity at large. Inequality of pay is, to be sure, only one form of inequality, but it is a pervasive and powerful one. We aim to demonstrate how unequal pay can vitiate the kind of relationships required to sustain relationally egalitarian justice, and a fortiori that equal pay, together with other forms of equality, is a condition of the possibility of sustaining relationally egalitarian justice.

The basic question of whether equal pay for all is desirable can be applied at two levels: that of society overall, which is the theme of this volume, and secondarily that of the individual workplace. Due to the appeal of establishing a sense of community at both of these levels, equality of pay in the workplace is a condition of a more relationally egalitarian workplace, and equality of pay across society is a condition of a relationally egalitarian polity.

Crucial to defending the claims we make about the effects of unequal pay is the Just World Fallacy. Previous research that has attempted to apply the Just World Fallacy to various ethical and political issues has focused on the obstacles it presents to egalitarianism in the form of psychological resistance (Kasperbauer 2015), whether or not a belief in a just world should be encouraged by parents and teachers (Kristjánsson 2004), and whether business organizations can constitute Aristotelian communities (Sinnicks 2020). We believe that the Just World Fallacy can also ground an argument in favour of equal pay for all.

\section{EQUALITY AND JUSTICE}

At the heart of the debate about the ends of justice is the question of what the aims of egalitarianism ought to be. Various accounts of equality - now grouped together under the heading of "luck egalitarianism" - hold that we ought to eliminate the effects of "brute luck" (Dworkin 2003; Arneson 1997) and so for luck egalitarians a distribution that makes individuals equal with respect to the effects of luck is what justice aims at, rather than say, an equal distribution or a distribution according to Rawls' difference principle. Arneson sets out the position succinctly:

Luck egalitarianism can be encapsulated in a slogan: It is morally bad - unfair and unjust - if some are worse off than others and morally good - just and fair - if all are equally well off. The 
injustice and unfairness of inequality are expunged if those who are worse off are so through their own fault or choice. (2012, p. 154)

Whether or not someone has a special talent for sprinting quickly, and thus can make a living as a professional athlete, and whether or not someone has a medical condition that prevents them from working full time, and thus being dependent on benefit payments, are matters of brute luck. Such factors, according to luck egalitarianism, should not determine my well-being, and so a fully just society would seek to overturn any reward or harm that results from such a fortuitous distribution of abilities and conditions. In reality, the outcomes of most lives depend on a complex interplay of option luck (the results of our free choices) and brute luck (external factors outside of our control that influence our lives). For this reason, amongst others, it may not be feasible for any real polity to fully "neutralize" such examples of brute luck, but to do so would be the conceptual, ethical, and philosophical ideal, and society is, according to the luck egalitarian, more or less just to the extent that this ideal, this pattern of distribution, is realized.

It is worth bearing in mind that there is a diverse array of goods which must be considered in order to provide a comprehensive account of justice. According to Wolff, "[d]istributive justice should be limited in its application by other egalitarian concerns" (1998, p. 122). This line of thinking is central to another line of egalitarian thought, most notably associated with Anderson (1999) who criticized accounts of distributive justice that focused on redistributing resources and argued instead that what we ought to want is a theory of justice which is founded on "equal respect and concern for all citizens" (Anderson 1999, p. 289). This is not to say that the relational egalitarian is unconcerned with distribution, indeed Anderson and Skorupski are clear that when "we reconceive equality as fundamentally a kind of social relationship than a pattern of distribution, we do not abandon distributive concerns. Rather, we give such concerns a rationale" (Anderson and Skorupski 2008, p. 143). It is however to say that on this view the "proper negative aim of egalitarian justice is not to eliminate the impact of brute luck from human affairs, but to end oppression, which by definition is socially imposed" (Anderson 1999, p. 288). This position is known as "democratic egalitarianism" or "relational egalitarianism" as it prioritizes the cultivation of the relationships which citizens must be able to enter into for a genuinely democratic community to function, rather than the promoting of particular patterns of income and wealth. While "ending oppression" and "equal respect" may sound like somewhat vague ends, in contrast to the relative clarity of luck egalitarianism and the framework of welfare economics that can underpin its application, Anderson has set out the position in greater detail. Specifically, relational egalitarianism is concerned with a social relation of equality of authority, status or standing between individuals as the end of justice; it claims inequality is unjust when inequality disadvantages people; it views justice as a virtue of agents (rather than, say, distributions); and it maintains that claims of justice are justified interpersonally rather than being objective facts about such-and-such a distribution (Anderson 2010, pp. 1-2). Since we can readily understand concepts such as equality of authority, status and standing, and since it is reasonably clear-cut when an individual is disadvantaged, this gives a good idea of what a relationally egalitarian society would look like and shines some light on what forms claims of justice (and injustice) should take.

These debates about relational and distributional equality have started to have an impact in business and organizational ethics. Néron persuasively argues that the reasons typically offered by egalitarians for their decision to ignore the corporation - namely "an obsessive focus on the justice of distributions, compounded by methodological priorities accorded to ideal theorizing 
about the principles of justice appropriate for the so-called "basic structure of society" (2015, p. 116) - are unconvincing. Instead, he suggests, "relational-egalitarian theorists are well placed to dive into the myriad justice issues inside the 'black box' of the modern business firm" (Néron 2015, p. 108). Our focus on community and justice means that there is a strong connection between arguments pertaining to organizations and to society at large. Indeed, as Néron (2010) notes, ethicists working in a variety of traditions have sought to understand businesses as political communities. Examples include work in the Kantian tradition (Robinson 2019), the Aristotelian tradition (Solomon 1994), the Thomistic tradition (Sison and Fontrodona 2012), stakeholder-theory (Freeman and Liedtka 1991) and indeed a variety of other perspectives (Heckscher and Adler 2007). Thus, the present chapter is, in part, an attempt to stimulate further discussion about relational equality within the literature on business and organizational ethics, as well as political philosophy. In what follows, we draw on research into the Just World Fallacy in order to argue the relationships required by relational egalitarianism require distributional equality, which in turn provides grounds for holding that equal pay for all is a worthy ideal. We thus identify a major obstacle to realizing a relationally egalitarian society (namely, unequal pay). In the words of Anderson and Skorupski (2008), we are attempting to give distributive concerns a further rationale within relational egalitarianism.

\section{THE JUST WORLD FALLACY}

Research into the Just World Fallacy reveals that when confronted with examples of injustice, experimental participants tend to show disdain for innocent victims and admiration for the undeservedly successful. In his original study Lerner (1965) found that participants who were told that a fellow student had won a cash prize in a random draw were inclined to believe that the student worked harder than another student who had not won the prize. This outcome led participants to draw the conclusion that the fortunate student in some way deserved the reward. This way of interpreting the fortuitous allocation of goods suggests that the recipients of rewards of whatever kind (including rewards of status, wealth, or authority) are therefore regarded as deserving those rewards, with the result that our relationships with them are colored by this fallacious inference.

Lerner and Simmons (1966) presented a subject in a paired-associate learning test, who was seemingly penalized for error through being subject to apparently violent electric shocks. When it was suggested by the investigator that this painful experiment would continue running, the participants "chose to devalue and reject the victim" (Lerner and Simmons 1966, p. 209), with participants tending to disdain the subject more as the apparent shocks increased in severity. A different tendency manifested when participants were told that the subject would receive financial compensation for successful responses in the learning task - specifically, the participants' disdain lessened considerably. Interestingly, where the participants were given the power to compensate the subject or to lessen their apparent pain they showed less disdain to the subject, but only when participants were certain that the compensation/reduced shocking would be realized. This suggests that even when the outcome is clearly not a matter of moral desert, the inclination to approbation/disapprobation remains. When the experiments were repeated, successful and unsuccessful subjects were likewise construed as deserving, respectively, their successes and failures. 
This phenomenon of victim-blaming is not limited to such cases as considered by Lerner and Simmons (1966). Other research on this topic has suggested that people are inclined to blame AIDS victims (Correia et al. 2001) and assault victims (Hammock and Richardson 1993) for the harms that have befallen them, that people are inclined to praise beneficiaries of gambling gains (Schmitt et al. 1991), and that the Just World Fallacy can lead to worse health outcomes for ethnic minorities (Hagiwara et al. 2015). Further work has shown that:

the evidence demonstrates that people are motivated not only to hold favourable attitudes toward themselves and toward members of their own groups...but also to hold favourable attitudes toward the existing social system and the status quo. What is especially significant is that system justification motives are sometimes capable of overriding ego and group justification motives associated with the protection of individual and collective interests and esteem. (Jost et al. 2004, p. 912)

Furthermore, the tendency for human judgement to fall foul of the Just World Fallacy has "been shown to be stable and cross-culturally generalizable" (Furnham 2003, p. 795).

Lerner's $(1965,1980)$ account of this psychological phenomenon, the "just world hypothesis", is that individuals need to construe the world in which they live as fundamentally just. This is so even in the face of decisive counterexamples involving random, or at least clearly unmerited, patterns of reward and harm, and positively or negatively evaluating individuals on the basis of these patterns - hence why it is called the Just World Fallacy. To quote Lerner and Miller, "[t]he just world hypothesis is easily stated: Individuals have a need to believe that they live in a world where people generally get what they deserve" (1978, p. 1050). According to Lerner and Simmons, "most people cannot afford, for the sake of their own sanity, to believe in a world governed by a schedule of random reinforcements" (1966, p. 203).

Research has shown this fallacy is manifested in introspective thinking as well as judgments of others. For instance, Ritter et al. observed as a result of their study that:

(1) the concepts of mastery and belief in a just world are statistically independent; (2) belief in a just world is negatively correlated with depressive affect; (3) belief in a just world affects the relationship between economic hardship and age and depression; and (4) belief in a just world does not moderate the relationship between economic hardship and depression. (1990, p. 247)

Thus, in addition to shaping our attitudes to and appraisals of others, and affecting our relationships to others, the Just World Fallacy also shapes our appraisals of and attitudes to ourselves which affects the relationships that others have with us. The self-derogation that can result from the Just World Fallacy is a severe obstacle to the ability of the less successful to regard themselves as equals with more successful colleagues. In light of the Just World Fallacy, it seems that distributive inequality - even if ostensibly deserved - will disrupt the ability of the less successful to challenge the more successful, which they must be able to do if there is to be shared, rational, intra-community deliberation.

\section{AN ARGUMENT FOR EQUAL PAY}

If everyone received equal pay, then the propensity for people to commit the Just World Fallacy would be diminished, and thus it would be more possible for people to enter into the sorts of relationships of equal respect and regard that just communities require. Of course, there are goods other than pay, and factors which shape - and perhaps distort - our appraisals of one 
another beyond the Just World Fallacy. Indeed, there are also other arguments which may count against equal pay for all, and there are considerations of justice that may outweigh the imperative to create and maintain communities in which relationships of equality can flourish. However, we believe that the Just World Fallacy constitutes a reason in favor of a presumption of equal pay and is an as-yet underappreciated phenomenon, that ought to be of greater concern to political philosophers and business and organizational ethicists.

Rawls' (1975) classic argument that inequality is justified if and only if it benefits the least well off may very well be a good candidate for the special justification required for unequal distributions of social goods, in this case pay. However, what research into the Just World Fallacy highlights is that even a financial benefit resulting from the existence of inequality is not necessarily an overall benefit, because distributive inequality can undermine participation in a community by undermining our ability to enter into relationships of equality. As advocates of relational equality are aware, the derogated victim of injustice is not necessarily better off simply in virtue of an income gain relative to an abstractly defined baseline because the derogation itself, and the change in relationships it entails, are themselves harms. Weighing the goods of communal relationships against the good of monetary gain is no easy matter, but it is not obvious that the latter ought to trump the former when we are trying to decide how to organize businesses and society.

We should however be clear: the Just World Fallacy is a propensity in some populations and not a psychological certainty, not all individuals have the same tendency to commit the Just World Fallacy (Rubin and Peplau 1975), and over a third of participants in Lerner and Simmons' (1966) study did not commit the fallacy. It is possible that these variations are not reflections of immutable individual differences, and thus it may be the case that under certain circumstances, we are able to cultivate a resistance to the Just World Fallacy. One form may be a suspicion of inequality. Emergency situations - hurricanes and earthquakes, the aftermath of terrorist attacks, and so on - often create a heightened sense of social solidarity, and in such circumstances people are far less tolerant of unequal distributions of various provisions. This point is powerfully made by Heath:

[e]mergencies typically evoke a higher level of social solidarity than everyday interactions, and so the norms governing them are often more egalitarian. As a matter of historical record, the norm that...governed the evacuation of the Titanic was "women and children first" - to the point where men were barred entirely from entering lifeboats on one side of the ship. (2014, p. 168)

In this vein, equal pay for all would be both a reflection of a sense of social solidarity, as well as a contributor to it. Equal pay would, a fortiori, support and consolidate the sorts of equal relationship required for relational egalitarianism to be realized. For those for whom social solidarity is an end in itself, this comprises a second argument for equal pay, but regardless, social solidarity is a plausible contender for inclusion in any list of conditions considered as part of the transcendental argument for what would have to be the case in order for a just society to exist. If we were to see unequal provisions of goods such as pay as reflective of a seriously misguided way of organizing society, we would, in virtue of that fact, be less prone to committing the Just World Fallacy, and make it easier to enter into the sorts of relationships required for relational egalitarianism to be brought about even in circumstances where inequality is present. Even just inequalities, rather than "patterns of fortuitous reward", can shape our appraisals of others in ways that may undermine our deliberative and judgemental capacities when the relevant judgements of praise or blame are reached in advance of the 
knowledge that such patterns of reward and harm are deserved, and equal pay could help to avoid this too.

On the other hand, if we know that someone deserves their lot (whether good or bad), this suggests we have got past the stage where the absence of information encourages us to use reward or harm as a heuristic. To know that someone deserves their receipt of some reward or harm is to know more about them than merely that they are in receipt of reward or harm, and this knowledge may allow us to reach conclusions that are not shaped by the Just World Fallacy. But opportunities to gain such information are scarce, particularly at the level of the polity, where relational egalitarianism most needs its relations of equal respect and regard to hold. The only way for this "desert argument" to work is if we could know that all distributions of goods are always and necessarily reflective of merit. However, it may be harder to construct a world in which unequal pay is unfailingly reflective of merit than a world in which everyone receives equal pay.

\section{CONCLUDING REMARKS}

The question of practical feasibility is not to be ignored. As Wolff notes, "things are very likely to go badly wrong if we set out an ideal theory of equality and then attempt to implement it in the real world without a great deal of further thought about how it would actually impact on people, and the relations between them" (2010, p. 349). Thus, we endorse equal pay for all more confidently at the level of the individual workplace. In such a context, there are fewer variables, and less complexity, than at the level of society as a whole. Furthermore, there is a greater possibility of community due to the relatively small scale of the organization, the possibility of a shared sense of purpose and clearer nature of shared commitments. At the level of the polity, or indeed the world, equal pay for all is a worthy aspiration and one that would make it easier for us to enter into relationships required for justice. There may, however, be other considerations that, in practice, outweigh it or at any rate make it more difficult to implement such as the motivational power of the prospect of a pay increase, or the possible advantages of the market more generally. Nevertheless, the consequences of the Just World Fallacy for our ability to accurately appraise others gives us a reason to be suspicious of inequality, and a reason to prefer equal pay for all.

\section{References}

Anderson, E. (1999). What is the point of equality? Ethics, 109(2), 287-337.

Anderson, E. (2010). The fundamental disagreement between luck egalitarians and relational egalitarians. Canadian Journal of Philosophy, 40(supp1), 1-23.

Anderson, E., \& Skorupski, J. (2008). Expanding the egalitarian toolbox: Equality and bureaucracy. Proceedings of the Aristotelian Society, 82(1), Supplementary Volume, 139-160.

Arneson, R.J. (1997). Egalitarianism and the undeserving poor. Journal of Political Philosophy, 5(4), 327-350.

Arneson, R. J. (2012). Rethinking luck egalitarianism and unacceptable inequalities. Philosophical Topics, 40(1), 153-169. 
Correia, I., Vala, J., Aguiar, P. (2001). The effects of belief in a just world and victim's innocence on secondary victimization, judgements of justice and Deservingness. Social Justice Research, 14(3), 327-342.

Dworkin, R. (2003). Equality, luck and hierarchy. Philosophy \& Public Affairs, 31(2), 190198.

Freeman, R. E., \& Liedtka, J. (1991). Corporate social responsibility: A critical approach. Business Horizons, 34(4), 92-98.

Furnham, A. (2003). Belief in a just world: Research progress over the past decade. Personality and Individual Differences, 34(5), 795-817.

Hagiwara, N., Alderson, C. J., McCauley, J. M. (2015). "We get what we deserve": The belief in a just world and its health consequences for Blacks. Journal of Behavioral Medicine, 38(6), 912-921.

Hammock, G. S., \& Richardson, D. (1993). Blaming drunk victims: Is it just world or sex role violation? Journal of Applied Social Psychology, 23(19), 1574-1586.

Heath J. (2014). Morality, competition and the firm. Oxford: Oxford University Press.

Heckscher, C., \& Adler, P. (2007). The firm as collaborative community. Oxford: Oxford University Press.

Jost, J. T., Banaji, M.R., Nosek, B.A. (2004). A decade of system justification theory: Accumulated evidence of conscious and unconscious bolstering of the status quo. Political Psychology, 25(6), 881-919.

Kasperbauer, T. J. (2015). Psychological constraints on egalitarianism: The challenge of just world beliefs. Res Publica, 21(3), 217-234.

Kristjánsson, K. (2004). Children and the belief in a just world. Studies in Philosophy and Education, 23(1), 41-60.

Lerner, M. J. (1965). Evaluation of performance as a function of performer's reward and attractiveness. Journal of Personality and Social Psychology, 1(4), 355-360.

Lerner, M. J. (1980). The Belief in a Just World: A Fundamental Delusion. New York, NY: Plenum Press.

Lerner, M. J., \& Miller, D. T. (1978). Just world research and the attribution process: Looking back and ahead. Psychological Bulletin, 85(5), 1030-1051.

Lerner, M. J., \& Simmons, C. H. (1966). Observer's reaction to the "innocent victim": Compassion or rejection? Journal of Personality and Social Psychology, 4(2), 203-210.

Néron, P. Y. (2010). Business and the polis: What does it mean to see corporations as political actors? Journal of Business Ethics, 94(3), 333-352.

Néron, P. Y. (2015). Rethinking the very idea of egalitarian markets and corporations: Why relationships might matter more than distribution. Business Ethics Quarterly, 25(1), 93-124.

Rawls, J. (1975). A theory of justice (revised edn.). Cambridge, MA: Harvard University Press. 
Ritter, C., Benson, D. E., Synder, C. (1990). Belief in a just world and depression. Sociological Perspectives, 33(2), 235-252

Robinson, R. (2019). The management nexus of imperfect duty: Kantian views of virtuous relations, reasoned discourse, and due diligence. Journal of Business Ethics, 157(1), 119-136.

Rubin, Z., \& Peplau, A. (1975). Who believes in a just world? Journal of Social Issues, 31(3), 65-89.

Schmitt, M., Kilders, M., Mösle, A., Müller, L. (1991). Gerechte-Welt-Glaube, Gewinn und Verlust: Rechtfertigung oder ausgleichende Gerechtigkeit? Zeitschrift für Sozialpsychologie, 22(1), 37-45.

Sinnicks, M. (2020). The just world fallacy as a challenge to the business-as-community thesis. Business \& Society, 59(6), 1269-1292.

Sison, A. J. G., \& Fontrodona, J. (2012). The common good of the firm in the AristotelianThomistic tradition. Business Ethics Quarterly, 22(2), 211-246.

Solomon, R. C. (1994). The corporation as community. Business Ethics Quarterly, 4(3), 271285.

Wolff, J. (1998). Fairness, respect, and the egalitarian ethos. Philosophy \& Public Affairs, 27(2), 97-122.

Wolff, J. (2010). Fairness, respect and the egalitarian ethos revisited. The Journal of Ethics, $14(3 / 4), 335-350$. 